\title{
ANALISIS KELOMPOK FAKTOR-FAKTOR KEMISKINAN DAN KESENJANGAN PEREKONOMIAN MENGGUNAKAN ALGORITMA SELF ORGANIZING MAPS (SOM) DI JAWA TENGAH TAHUN 2015
}

\author{
Siti Hasna Isnaeni ${ }^{1}$ \\ * Statistika, FMIPA, Universitas Islam Indonesia \\ *s.hasna.isnaeni@gmail.com ${ }^{1}$
}

\begin{abstract}
The problem of poverty continues to be a major problem throughout Indonesia's history as a State. The distribution of the poor is also uneven in all regions in Indonesia. In the theory of poverty mentioned that the factors that influence the emergence of poverty problems originated from limitations in terms of economic, whether physical capital (income) or human capital. Therefore, poverty reduction target oriented planning is needed, so that the poverty reduction and economic disparity can be achieved by target. This study aims to analyze the factors that affect poverty and economic inequality to know the characteristics by applying data mining algorithms to determine the grouping of poverty and economic disparities in Central Java in 2015. In the grouping of poverty factors, the object of research that will be used are variables affecting poverty and economic disparity.The group analysis used data mining approach with Kansans and Kohonen Self Organizing Maps (SOM) algorithm.The result of analysis based on WCSS graph and cluster number validation is determined by cluster number 5 with Semarang City as cluster 1, Kudus is in cluster 2, cluster 3 contains 5 cities, in cluster 4 containing 6 districts and 22 other districts are in cluster 5.
\end{abstract}

Keywords: Poverty, Economic Gap, Clustering K-means, Self Organizing Maps (SOM),central java.

\section{Pendahuluan}

Persoalan kemiskinan merupakan persoalan rumit yang tidak memiliki ujung pangkal. Hal itu dikarenakan, banyak faktor yang dapat menyebabkan munculnya masalah kemiskinan, begitu juga kemiskinan dapat memunculkan masalah ekonomi pembangunan lainnya. Dalam Mudrajad (2006:120) penyebab kemiskinan akan bermuara pada teori lingkaran setan kemiskinan (vicious cycle of poverty). Adanya keterbelakangan, ketidaksempurnaan pasar dan kurangnya modal menyebabkan rendahnya produktifitas. Rendahnya produktifitas menyebabkan rendahnya pendapatan yang mereka terima. Rendahnya pendapatan akan mengakibatkan rendahnya pula tabungan. Rendahnya tabungan maka rendah pula investasinya.

$$
\text { Kemiskinan sendiri merupakan }
$$

ketidakmampuan manusia dalam memenuhi kebutuhan hidupnya. Penduduk miskin adalah penduduk yang memiliki rata-rata pengeluaran perkapita perbulan di bawah Garis Kemiskinan (BPS Provinsi Jawa Tengah, 2012).

Riset Akuntansi dan Keuangan Indonesia, 3(1), 2018
Problematika kemiskinan terus menjadi masalah besar sepanjang sejarah Indonesia sebagai sebuah Negara. Sebaran penduduk miskin juga tidak merata di seluruh Wilayah Kepulauan Indonesia. Penduduk Indonesia jika dilihat dari sisi sebaran jumlah penduduk miskin tahun 2011 - 2012, sebagian besar penduduk miskin terkonsentrasi di Pulau Jawa. Sebagaimana yang ditunjukkan oleh Grafik 1.1, lebih dari $538 \mathrm{Ribu} / \mathrm{jiwa}$ penduduk miskin berada di Jawa, di Bali dan Maluku sebanyak 400 Ribu/jiwa, di Sumatera dan Sulawesi sebesar 300 Ribu/jiwa dan yang terakhir yakni pulau Kalimantan hanya sebesar 200 Ribu/jiwa. Pemusatan kantong kemiskinan di Pulau Jawa erat kaitannya dengan pola persebaran penduduk yang sebagian besar berada di Pulau ini. Meskipun luasnya hanya sepertiga dari luas seluruh daratan Indonesia, tetapi Pulau Jawa merupakan tempat tinggal bagi sekitar 60 persen penduduk Indonesia yang mencapai sekitar 237,6 juta (BPS, 2010).

Berdasarkan latar belakang diatas, maka penulis akan mengaplikasikan Kohonen's SelfOrganizing Maps dalam kasus segmentasi wilayah 
berdasarkan parameter-parameter yang merupakan indikator kemiskinan dan kesenjangan perekonomian. Parameter-parameter yang dimaksud yaitu, jumlah penduduk tahun 2015, Angka partisipasi kasar, pengangguran, jumlah penduduk miskin, Produk Domestik Regional Bruto (PDRB), pengeluaran perkapita (IPM), presentase penduduk miskin, bekerja di sektor pertanian, gini ratio. Alasan penulis menggunakan algoritma Kohonen yaitu karena Kohonen merupakan algoritma yang efektif untuk memvisualisasikan data berdimensi tinggi dengan cara mereduksi dimensinya dari sebuah input n-dimensi ke dimensi yang lebih rendah dengan tetap mempertahankan hubungan topologi aslinya. Selain itu, Kohonen's Self-Organizing Maps merupakan pendekatan nonparametrik yang tidak membutuhkan asumsi mengenai distribusi populasi.

Tujuan dari tulisan ini adalah mengetahui gambaran hasil analisis cluster untuk kemiskinan dan kesenjangan perekonomian di Jawa Tengah Tahun 2015 dengan menggunakan metode Self Organizing Maps dan mengetahui karakteristik kemiskinan dan kesenjangan perekonomian berdasarkan kabupaten/kota yang terdapat di Jawa Tengah tahun 2015.

\section{Kajian Pustaka dan Pengembangan Hipotesis}

Terdapat beberapa penelitian terdahulu yang berkaitan dengan metode analisis Self Organizing Maps (SOM) dan kemiskinan sesuai dengan latar belakang pendidikan dan sudut pandang yang berbeda diantaranya adalah :

Septianusa dkk (2014) dengan melakukan segmentasi kondisi pertanian padi di tiap wilayah Provinsi Jawa Tengah. Hal ini ditujukan dalam mendeskripsikan sifat dan karakteristik masing-masing kelompok sehingga dicapai target produksi padi diatas 10 juta ton pada tahun 2014. Pada penelitian ini menggunakan analisis deskriptif untuk menggambarkan keadaan pertanian padi di Provinsi Jawa Tengah dan Implementasi Kohonen's Self Organizing Maps untuk proses segementasi guna mendapatkan hasil visualisasi dan cluster kondisi pertanian padi.

Muhammad Sri Wahyudi Suliswanto (2010) menemukan bahwa Data yang digunakan dalam penelitian ini adalah data PDRB dan IPM seluruh provinsi di Indonesia tahun 2006 - 2008. Dengan menggunakan metode analisis regresi data panel dengan model FEM dan REM.

Secara harfiah kata "miskin" dapat diartikan sebagai "serba kekurangan", sementara "kemiskinan" dipandang sebagai sebuah kondisi / keadaan serba kekurangan baik dalam bentuk fisik maupun materi. Dalam arti sempit, kemiskinan dapat dipahami sebagai sebuah keadaan serba kekurangan untuk menjamin keberlangsungan hidup. Dalam arti yang lebih luas, menurut Chambers (dalam Nita Anggraini, 2012) kemiskinan adalah suatu konsep yang terintegrasi dengan lima dimensi yaitu: 1) kemiskinan, 2) ketidakberdayaan, 3) kerentanan menghadapi situasi darurat, 4) ketergantungan, dan 5) keterasingan baik secara geografis maupun sosiologis.

Kemiskinan memiliki konsep yang beragam, sehingga dalam penentuan ukuran kemiskinanpun ikut beragam. Beberapa indikator ukuran kemiskinan telah banyak beredar di masyarakat. Salah satunya, Adanya keberagaman ukuran indikator kemiskinan inilah yang menyulitkan penafsiran mengenai permasalahan kemiskinan. Oleh karenanya untuk memberi kemudahan dalam penafsiran ukuran, maka setiap negara menetapkan sebuah batasan pengukuran kemiskinannya masing-masing. Batasan ukuran itu dikenal sebagai garis kemiskinan. Garis kemiskinan merupakan garis batas kebutuhan minimum, untuk mengkategorikan seseorang dianggap miskin atau tidak. Garis kemiskinan berfungsi mewakili ciri-ciri warga miskin yang biasanya pengukuran tersebut didasarkan pada ukuran pendapatan atau pengeluaran dari seseorang.

Menurut World Bank, kategori miskin ditentukan oleh perolehan pendapatan per hari seseorang. Kategorinya adalah jika pendapatan orang tersebut per harinya dibawah US\$ 1,25 - 2 per hari, maka orang itu dapat dikatakan dalam kondisi miskin.

Selain itu, adapun masalah mengenai penyebab kemiskinanpun turut bermunculan melalui sejumlah penelitian yang ada. Menurut Sharp (dalam Mudrajat Kuncoro, 2006), terdapat 3 faktor penyebab kemiskinan jika dipandang dari segi ekonomi. Penyebab pertama muncul karena adanya ketidaksamaan pola kepemilikan sumberdaya yang menimbulkan distribusi pendapatan yang timpang. Penduduk miskin umumnya hanya memiliki sumberdaya yang terbatas dan kualitasnya rendah. 
Penyebab kedua muncul akibat perbedaan dalam kualitas sumberdaya manusia. Kualitas sumberdaya manusia yang rendah berarti produktivitasnya rendah, yang pada gilirannya upah turut rendah. Rendahnya kualitas sumberdaya ini disebabkan karena rendahnya pendidikan, nasib yang kurang beruntung, adanya diskriminasi, atau keturunan. Penyebab terakhir muncul karena adanya perbedaan akses dalam modal.

Analisis deskriptif adalah suatu cara menggambarkan persoalan yang berdasarkan data yang dimiliki yakni dengan cara menata data tersebut sedemikian rupa sehingga dengan mudah dapat dipahami tentang karakteristik data, dijelaskan dan berguna untuk keperluan selanjutnya. Jadi dalam hal ini terdapat aktivitas atau proses pengumpulan data dan pengolahan data berdasarkan tujuannya. Febrianita dalam (Setianingsih, 2016).

Menurut Kuncoro dalam (Pratama, 2015), clustering adalah teknik yang digunakan untuk mengidentifikasi objek atau individu yang serupa dengan memperhatikan beberapa kriteria. Clustering yaitu analisis untuk mengelompokkan elemen yang mirip sebagai objek penelitian menjadi kelompok (cluster) yang berberda dan mutually exclusive.

Menurut Supranto (2004), konsep pengukuran jarak merupakan pendekatan yang paling biasa dalam mengukur kemiripan antara pasangan objek. Pasangan objek dengan jarak yang lebih pendek akan lebih mirip dibandingkan pasangan objek yang jaraknya lebih panjang. Ada beberapa cara untuk mengukur jarak antara dua objek, diantaranya:

a. Jarak euclidean adalah akar dari jumlah kuadrat perbedaan atau deviasi di dalam nilai untuk setiap variabel. Jarak euclidean adalah pengukuran jarak yang paling biasa digunakan. (Supranto, 2004)

Menurut Simammora, nilai $d_{i j}$ diperoleh melalui perhitungan jarak kuadrat euclidean. Jarak eucliden yang dirumuskan sebagai berikut:

$$
d(i j)=\sqrt{\sum_{k=1}^{p}\left(x_{i k}-x_{j k}\right)^{2}}
$$

Dimana:

$$
\begin{array}{ll}
d(i j) & =\text { jarak antara objek i dan objek j } \\
x_{i k} & =\text { nilai objek i pada variabel ke k } \\
x_{j k} & =\text { nilai objek i pada variabel ke k }
\end{array}
$$

$p \quad=$ banyak varaibel yang diamati

b. Manhattan distance atau the city blok distance adalah jumlah perbedaan mutlak/absolut di dalam nilai untuk setiap variabel.

$$
d(i j)=\sum_{k=1}^{p}\left|x_{i k}-x_{j k}\right|
$$

\section{Dimana :}

$$
\begin{array}{ll}
d(i j) & =\text { jarak antara objek } \mathrm{i} \text { dan objek } \mathrm{j} \\
x_{i k} & =\text { nilai objek i pada variabel ke } \mathrm{k} \\
x_{j k} & =\text { nilai objek i pada variabel ke } \mathrm{k} \\
p & =\text { banyak varaibel yang diamati }
\end{array}
$$

Pekerjaan yang dapat dilakukan dengan SOM antara lain untuk clustering, dalam konteks clustering, SOM dapat digunakan sebagai pengelompokan alternative selain $K$ Means. Diketahuinya jumlah cluster SOM akan membagi data yang tersedia ke kelompok yang berbeda. Keuntungan utama dari SOM adalah cenderung lebih sedikit mendapatkan hasil percabangan daripada menggunakan algoritma $K$ Means, dan dapat digunakan sebagai algoritma inisialisasi yang baik untuk metode $K$ Means. Faktanya, SOM dapat disubstitusikan dengan K Means bersamaan dan pada algoritma training SOM menghasilkan algoritma yang sama dengan K Means. Kelebihan lainnya dari algoritma SOM adalah diperolehnya suatu urutan topologis yang biasanya cluster yang mirip disusun bersama (Lobo, 2009).

\section{Metode Penelitian}

\section{Populasi dan sampel penelitian}

Populasi penelitian ini adalah segala kondisi yang berkaitan dengan kemiskinan serta kesenjangan perekonomian di Jawa Tengah dan dan keadaan di tahun 2015 diambil sebagi sampel penelitiannya.

\section{Tempat dan Waktu Penelitian}

Penelitian tugas akhir ini dilakukan pada bulan Februari 2017 - Mei 2017. Lokasi yang dipilih untuk penelitian ini adalah seluruh wilayah Jawa Tengah. Data tersedia yang akan diteliti diperoleh dari data Badan Pusat Statistik yang tercatat pada tahun 2015.

\section{Variabel Penelitian}

Data yang digunakan adalah data sekunder yang didapatkan dari Publikasi BPS Jawa Tengah tahun 2015 yaitu "Faktor-faktor kemiskinan dan kesenjangan perekonomian 2015" pada website Badan 
Pusat Statistik Indonesia http://www.bps.go.id Variabel yang digunakan dalam penelitian ini adalah :

1. Penduduk Miskin adalah penduduk yang memiliki rata-rata pengeluaran perkapita perbulan dibawah garis kemiskinan.

2. Rasio Gini atau koefisien adalah alat mengukur derajat ketidakmerataan distribusi penduduk. Ini didasarkan pada kurva Lorenz, yaitu sebuah kurva pengeluaran kumulatif yang membandingkan distribusi dari suatu variable tertentu (misalnya pendapatan) dengan distribusi uniform (seragam) yang mewakili persentase kumulatif penduduk.

3. Pengangguran adalah istilah untuk orang yang tidak bekerja sama sekali, sedang mencari kerja, bekerja kurang dari dua hari selama seminggu, atau seseorang yang sedang berusaha mendapatkan pekerjaan yang layak.

4. Persentase penduduk miskin adalah persentase penduduk yang berada dibawah Garis Kemiskinan (GK).

5. Angka Partisipasi Kasar (APK) : Proporsi anak sekolah pada suatu jenjang tertentu dalam kelompok usia yang sesuai dengan jenjang pendidikan tersebut

6. Pekerja di pertanian, adalah seseorang yang bekerja pada orang lain/majikan/institusi yang tidak tetap (lebih dari 1 majikan dalam sebolan terakhir) di usaha pertanian baik berupa usaha rumah tangga maupun bukan usaha rumah tangga atas dasar balas jasa dengan menerima upah atau imbalan baik berupa uang maupun barang, dan baik dengan sistem pembayaran harian maupun borongan.

7. PDRB ialah Produk domestik regional bruto per-kapita atas dasar harga yang berlaku di Jawa Tengah tahun 2015.

8. Pengeluaran perkapita riil adalah total pengeluaran perkapita/bulan untuk makanan dibagi dengan total pengeluaran/kapita perbulan untuk makanan dan non makanan.

\section{Metode Pengumpulan Data}

Data dalam penelitian ini adalah data sekunder yaitu data yang diperoleh atau dikumpulkan dari sumber-sumber yang telah ada. Data yang digunakan adalah data dari hasil pencatatan yang telah dipublikasikan oleh Badan Pusat Statistik Jawa
Tengah, pengumpulan data sekunder yang digunakan adalah dengan mencatat data yang sudah ada.

\section{Metode Analisis Data}

Penelitian ini menggunakan analisis kelompok dengan Self Organizing Maps dan K Means, untuk validasi cluster menggunakan cluster variance dan juga membandingkan hasil pengelompokan kedua algoritma dengan pengelompokan kabupaten yang dilakukan oleh pemerintah Jawa Tengah.

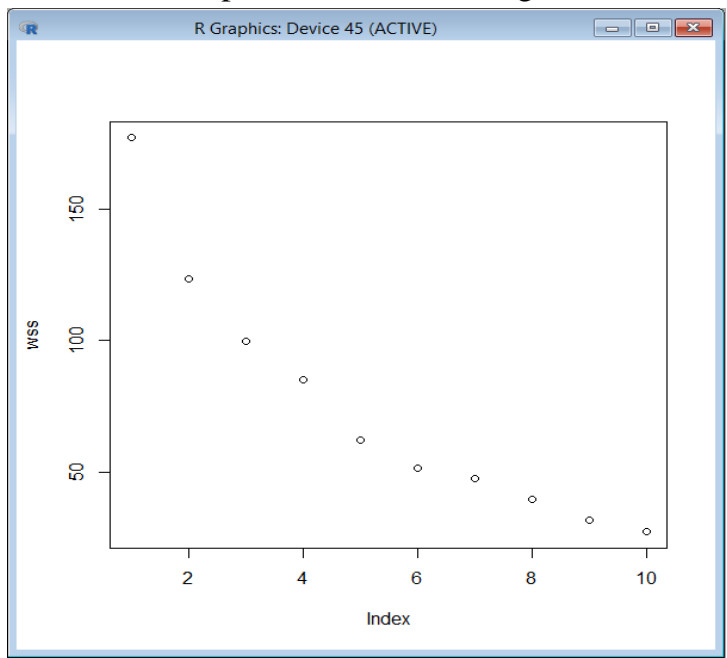

Gambar 1.1 Within Cluster Sum of Squares (WCSS)

Dari within cluster sum of squares di atas, terlihat pada saat terbentuk satu cluster, kurva masih menunjukkan kecuraman dan semakin landai sesuai dengan pertambahan cluster. Pada intinya semakin banyak jumlah cluster yang terbentuk maka jumlah anggota yang tergabung semakin sedikit.

Belum ada penelitian sebelumnya yang berkaitan dengan pengelompokan kabupaten di Jawa Tengah berdasarkan faktor-faktor kemiskinan dan kesenjangan perekonomian di Jawa Tengah Tahun 2015, oleh karena itu peneliti menggunakan pendekatan penentuan jumlah cluster menjadi 5 kelompok menggunakan metode Self Organizing Maps. Alasan peneliti memilih pengelompokan menjadi 5 adalah karena pada grafik Within Cluster Sum of Squares pada saat diangka 5, note atau titik sudah mulai landai walaupun di angka yang lebih besar ada yang lebih landai akan tetapi jika jumlah cluster semakin banyak maka hasilnya kurang efektif karena terlalu banyak cluster. 


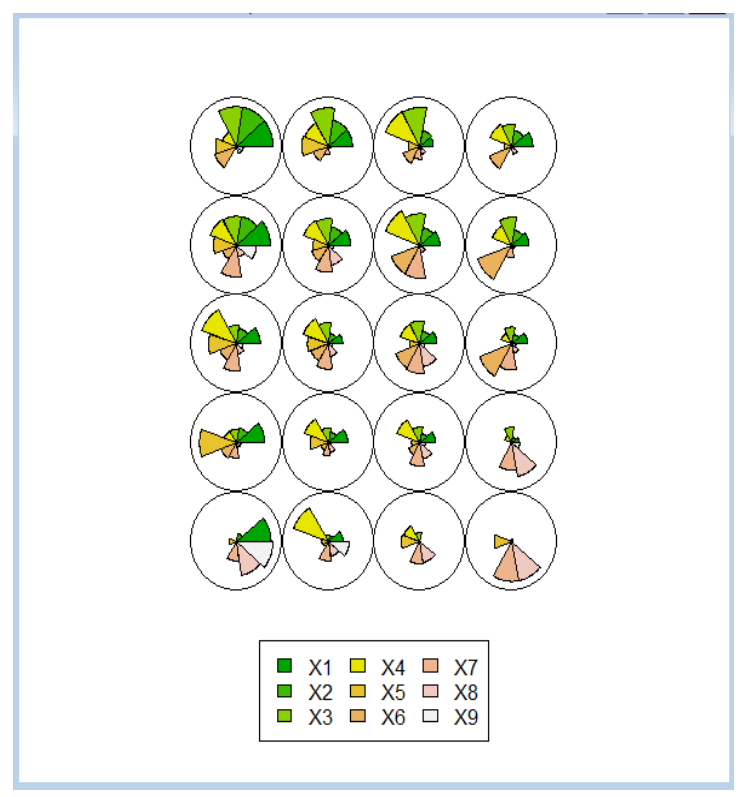

Gambar 1.2 Fan diagram

Dari gambar 1.2 dapat dilihat penulis membuat fan diagram menggunakan tampilan rectangular dengan grid 4 x 5 . Diagram di atas dibentuk berdasarkan hasil data olah dengan algoritma kohonen menggunakan sembilan variabel. Dari fan diagram tersebut dapat diketahui penggambaran dan pewarnaan untuk masing- masing variabel yaitu : jumlah penduduk 2015 diberi warna Hijau pekat, jumlah penduduk miskin diberi warna hijau, persentase penduduk miskin diberi warna hijau muda, angka partisipasi kasar diberi warna kuning, pengangguran diberi warna orange, bekerja disektor pertanian diberi warna peach, gini ratio diberi warna pink pekat, pengeluaran perkapita riil diberi warna pink muda, Produk Domestik Regional Bruto (PDRB) diberi warna putih. Fan diagram menunjukkan distribusi dari variabel pada peta. Pola dapat dilihat dengan memeriksa warna yang dominan.

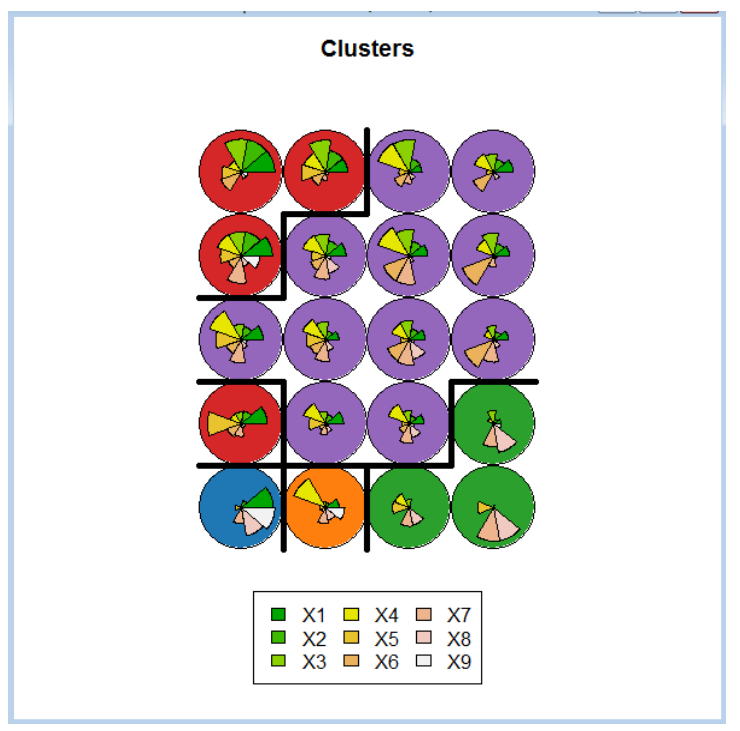

Gambar 1.3 Karakteristik masing-masing cluster

Dari gambar 1.3 dapat dilihat model yang terbentuk dengan algoritma Kohonen kemudian dibentuk menjadi lima cluster dengan metode hierarki cluster. Dari masing-masing cluster yang terbentuk memiliki karakteristik tersendiri. Cluster 1 ditandai dengan warna biru, cluster 2 ditandai dengan warna orange, cluster 3 ditandai dengan warna hijau, cluster 4 ditandai dengan warna merah, cluster 5 ditandai dengan warna ungu. Berikut adalah karakteristik dari masing-masing cluster:

Dari gambar 1.3 dapat dilihat bahwa terbentuk 5 cluster dengan anggota masing-masing cluster sebagai berikut :

1. Cluster 1 : Kota Semarang

2. Cluster 2 : Kudus

3. Cluster 3 : Kota Magelang, Kota Surakarta, Kota Salatiga, Kota Pekalongan, dan Kota Tegal.

4. Cluster 4 : Cilacap, Banyumas, Kebumen, Pemalang, Tegal, dan Brebes.

5. Cluster 5 : Purbalingga, Banjarnegara, Purworejo, Wonosobo, Magelang, Boyolali, Klaten, Sukoharjo, Wonogiri, Karanganyar, Sragen, Grobogan, Blora, Rembang, Pati, Jepara, Demak, Semarang, Temanggung, Kendal, Batang, dan Pekalongan. 
Tabel 1.1 Jumlah dan Anggota Kelompok

menggunakan Self Organizing Maps

\begin{tabular}{|c|c|l|}
\hline Kelompok & $\begin{array}{l}\text { Jumlah } \\
\text { Anggota }\end{array}$ & Anggota Kelompok \\
\hline 1 & 1 & Kota Semarang \\
\hline 2 & 1 & Kudus \\
\hline 3 & 5 & $\begin{array}{l}\text { Kota Magelang, Kota } \\
\text { Surakarta, Kota Salatiga, } \\
\text { Kota Pekalongan, dan } \\
\text { Kota Tegal }\end{array}$ \\
\hline 4 & 6 & $\begin{array}{l}\text { Cilacap, Banyumas, } \\
\text { Kebumen, Pemalang, } \\
\text { Tegal, dan Brebes }\end{array}$ \\
\hline 5 & 22 & $\begin{array}{l}\text { Purbalingga,Banjarnegara } \\
\text { Purworejo,Wonosobo, } \\
\text { Magelang,Boyolali,Klate } \\
\text { n, Sukoharjo,Wonogiri, } \\
\text { Karanganyar,Sragen, } \\
\text { Grobogan, Blora, } \\
\text { Rembang, Pati, Jepara, } \\
\text { Demak,Semarang,Teman } \\
\text { ggung, Kendal,Batang, } \\
\text { dan Pekalongan. }\end{array}$ \\
\hline \multicolumn{2}{|c|}{ Karakteristik } \\
terbentuk adalah :
\end{tabular}

1. Jumlah penduduk, Pengeluaran perkapita riil, dan PDRB tinggi, jumlah penduduk miskin, Angka Partisipasi Kasar rendah dan bekerja disektor pertanian sedang.

2. Angka partisipasi kasar tinggi, gini ratio, pengeluaran perkapita riil, PDRB, dan jumlah penduduk tinggi, dan jumlah penduduk miskin, pengangguran rendah.

3. Gini ratio, pengeluaran perkapita riil tinggi, angka partisipasi kasar, pengangguran sedang, dan persentase penduduk miskin, PDRB, jumlah penduduk rendah.

4. Jumlah penduduk, jumlah penduduk miskin, persentase penduduk miskin, dan pengangguran tinggi, angka partisipasi kasar, gini ratio sedang dan PDRB, bekerja di sektor pertanian rendah.

5. Persentase penduduk miskin, bekerja disektor pertanian, gini ratio, angka partisipasi kasar tinggi, jumlah penduduk, jumlah penduduk miskin, pengeluaran perkapita riil sedang, dan pengangguran rendah.
Tabel 1.2 Tabel nilai rata-rata variabel pada setiap cluster

\begin{tabular}{|c|c|c|c|c|c|}
\hline & Cluster 1 & Cluster 2 & Cluster 3 & Cluster 4 & Cluster 5 \\
\hline Jumlah Penduduk & 1701.11 & 831.30 & 271.87 & 1501.727333 & 948.7274545 \\
\hline $\begin{array}{l}\text { Jimlah pendudulk } \\
\text { niskin }\end{array}$ & 84.3 & 64.1 & 24.32 & 250.3833333 & 127.509009 \\
\hline $\begin{array}{l}\text { Persentase } \\
\text { Penduduk Miskin }\end{array}$ & 4.97 & 7.73 & 8.418 & 16.755 & 13.67136364 \\
\hline $\begin{array}{l}\text { Angka Partisipasi } \\
\text { Kasarar }\end{array}$ & 100.54 & 116.3 & 105.612 & 109.88 & 111.2118182 \\
\hline Pengangguran & 32.7 & 32.5 & 37.444 & 43.805 & 34.2627272 \\
\hline dị seltor pertanian & 3.3 & 7.81 & 2.372 & 24.56 & 33.76818182 \\
\hline gini ratio & 0.33 & 0.33 & 0.348 & 0.325 & 0.331363636 我 \\
\hline $\begin{array}{l}\text { pengeduaran } \\
\text { perkapitata }\end{array}$ & 13589 & 10203 & 1239996 & 8650.833333 & 9551.181818 \\
\hline$P D R B$ & $109,141,554$ & $65,183,803$ & 11288957.59 & 328811157.05 & 171711942.41 \\
\hline
\end{tabular}

Hasil Cluster 1 memiliki rata-rata jumlah penduduk paling tinggi dibanding cluster lainnya sebanyak 1.701,11 (ribu/jiwa). Jumlah ini termasuk paling kecil diantara cluster lainnya yaitu sebanyak 4,97, atau kurang dari setengahnya dari total jumlah penduduknya dan hanya sebanyak 3,3 persen yang kerja di sektor pertanian. Jika dilihat dari faktor perekonomian yaitu gini ratio, pengeluaran perkapita riil, dan PDRB, cluster 1 memiliki rata-rata gini ratio yang lumayan tinggi sebanyak 0,33 , rata-rata jumlah pengeluaran perkapita 13589 dan rata-rata jumlah PDRB sebanyak 109.141.554. Kemudian untuk APK dan Pengangguran dari faktor kemiskinan pada cluster 1 memiliki nilai yang paling rendah diantara cluster yang ada yaitu dengan rata-rata APK sebesar 100,54 dan pengangguran 32,7 .

Cluster 2 memiliki rata-rata jumlah penduduk miskin sebanyak 64,1 dari rata-rata jumlah penduduk sebanyak 831,30 (ribu/jiwa). Jumlah ini adalah yang terendah kedua setelah cluster 3, akan tetapi pada cluster 2 memiliki rata-rata jumlah APK paling banyak dibanding cluster lainnya yaitu sebanyak 116,3, walaupun begitu, rata-rata jumlah penganggurannya paling rendah sebesar dengan 32,5. Jika dilihat dari faktor kesenjangan ekonominya yaitu jumlah gini ratio, pengeluaran perkapita, dan PDRB cluster 2 memiliki rata-rata jumlah gini ratio sebanyak 0,33 , rata-rata jumlah pengeluaran perkapita sebesar 10203 dan rata-rata jumlah PDRB sebanyak 65.183.803 paling besar kedua. Kemudian untuk yang bekerja disektor pertanian sebesar 7,81.

Cluster 3 memiliki rata-rata jumlah penduduk miskin dan rata-rata jumlah penduduk paling rendah 
dibanding cluster lainnya sebanyak 24,32 (ribu/jiwa) Jumlah ini, dari jumlah rata- rata penduduk cluster 3 yaitu berjumlah 271,87 (ribu/jiwa) dibandingkan dengan cluster lainnya. Tetapi memiliki persentase jumlah penduduk miskin yang lumayan tinggi di banding cluster lainnya. Jika dilihat dari faktor ekonomi yaitu jumlah gini ratio, pengeluaran perkapita riil, dan PDRB, cluster 3 memiliki rata-rata jumlah gini ratio sebanyak 0,348 , rata-rata jumlah pengeluaran perkapita riil sebanyak 12.399,6 terbanyak kedua setelah cluster 1 dan rata-rata jumlah PDRB sebanyak 11288957,59. Pada cluster 3 memiliki jumlah pengangguran, bekerja disektor pertanian dan APK adalah yang paling tinggi kedua sebesar 37,444, paling rendah yaitu sebesar 2,372 dan terkecil kedua setelah cluster 1 sebesar 105,612.

Cluster 4 merupakan cluster dengan rata-rata jumlah penduduk miskin paling tinggi dibanding cluster lainnya sebanyak 250,3833333, dari jumlah penduduk sebanyak 1501,727333 , nilai paling tinggi kedua setelah cluster 1 dan persentase penduduk miskin tertinggi juga sebesar 16,755. Jika dilihat dari faktor ekonomi yaitu jumlah gini ratio, pengeluaran riil, dan PDRB, cluster 4 memiliki rata-rata jumlah gini ratio sebanyak 0,325 , rata-rata jumlah pengeluaran perkapita riil sebesar 8650,833333, nilai terkecil dibanding cluster lainnya, dan rata-rata jumlah PDRB sebanyak 32881157,05. Kemudian untuk APK, Pengangguran,dan bekerja di sektor pertanian pada cluster 4 memiliki nilai sebesar 109,88, dengan nilai pengangguran sebesar 43,805, dimana nilai pengangguran tersebut ialah yang paling tinggi, dan sebesar 24,56. Dapat dikatakan bahwa cluster 4 adalah daerah dengan faktor-faktor kemiskinan dan kesenjangan ekonomi yang tertinggi dari daerah lainnya karena cluster 4 memiliki tingkat kemiskinan yang tinggi dan perekonomian rendah diantara cluster lainnya hampir di semua aspek.

Cluster 5 merupakan cluster dengan rata-rata jumlah penduduk miskin sebesar 127,5909091 dari jumlah penduduk sebanyak 948,7274545, dengan persentase penduduk miskin sebesar 13,67136364 dimana nilai tersebut nilai paling tinggi kedua setelah cluster 4. Jika dilihat dari faktor ekonomi yaitu jumlah gini ratio sebesar 0,331363636 , pengeluaran perkapita riil sebesar 9551,181818 dan PDRB sebesar 17171942,41. Kemudian untuk APK sebesar 111,2118182 nilai tertinggi, Pengangguran sebanyak

Riset Akuntansi dan Keuangan Indonesia, 3(1), 2018
34,26272727 , dan yang bekerja di sektor pertanian sebesar 33,76818182.

Adapun hasil pemetaan dari analisis clustering menggunakan SOM ini adalah:

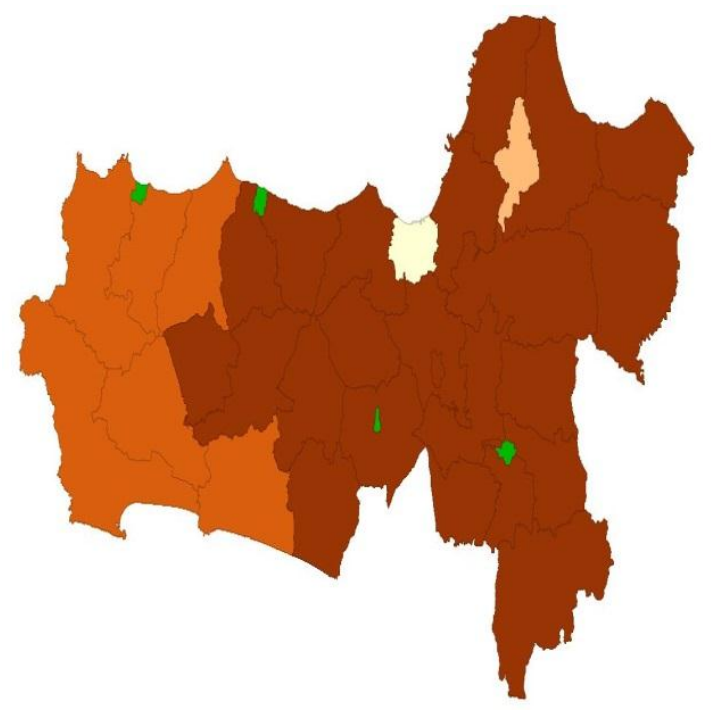

Gambar 1.4 Pemataan Menggunak Self Organizing Maps

Hasil dan Pembahasan

\section{Simpulan}

Berdasarkan hasil analisis dan pembahasan, peneliti mengambil kesimpulan sebagai berikut:

1. Kemiskinan dan kesenjangan ekonomi di Jawa Tengah masih belum signifikan antar tiap Kabupaten, terbukti dengan besarnya perbedaan antar tiap Kabupaten di Jawa Tengah hal ini disebabkan oleh masih belum merata perekonomian di Jawa Tengah dan persebaran penduduk yang belum merata.

2. Hasil cluster dengan menggunakan metode SOM menghasilkan kelompok 1 yang terdiri dari Kota Semarang diasosiasikan dalam lingkaran berwarna biru. Kelompok 2 Kudus berwarna orange kemudian kelompok 3 Kota Magelang, Kota Surakarta, Kota Salatiga, Kota Pekalongan, dan Kota Tegal diasosiasikan lingkaran yang berwarna hijau, untuk kelompok 4 yang terdiri dari Kabupaten Cilacap, Banyumas, Kebumen, Pemalang, Tegal, dan Brebes diasosiasikan kedalam lingkaran berwarna Merah. Dan kelompok yang terakhir yang berisi 22 
Kabupaten yaitu Purbalingga, Banjarnegara, Purworejo, Wonosobo, Magelang, Boyolali, Klaten, Sukoharjo, Wonogiri, Karanganyar, Sragen, Grobogan, Blora, Rembang, Pati, Jepara, Demak, Semarang, Temanggung, Kendal, Batang, dan Pekalongan.

3. Cluster 1 memiliki Jumlah penduduk, Pengeluaran perkapita riil, dan PDRB tinggi, jumlah penduduk miskin, Angka Partisipasi Kasar rendah dan bekerja disektor pertanian sedang, Cluster 2 memiliki Angka partisipasi kasar tinggi, gini ratio, pengeluaran perkapita riil, PDRB, dan jumlah penduduk tinggi, dan jumlah penduduk miskin, pengangguran rendah, Cluster 3 memiliki Gini ratio, pengeluaran perkapita riil tinggi, angka partisipasi kasar, pengangguran sedang, dan persentase penduduk miskin, PDRB, jumlah penduduk rendah, Cluster 4 memiliki Jumlah penduduk, jumlah penduduk miskin, persentase penduduk miskin, dan pengangguran tinggi, angka partisipasi kasar, gini ratio sedang dan PDRB, bekerja di sektor pertanian rendah, Cluster 5 memiliki Persentase penduduk miskin, bekerja disektor pertanian, gini ratio, angka partisipasi kasar tinggi, jumlah penduduk, jumlah penduduk miskin, pengeluaran perkapita riil sedang, dan pengangguran rendah.

\section{Saran}

Berdasarkan kesimpulan yang diperoleh dari analisis, maka diberikan saran-saran sebagai berikut :

1. Untuk penelitian selanjutnya, sebaiknya peneliti juga melibatkan faktor - faktor lain yang mempengaruhi kemiskinan dan kesenjangan dengan pemutakhiran data terbaru. Pada pengaplikasian pemetaan berupa peta dasar sebagai visualisasi dari hasil pengelompokan, sebaiknya dibuat lebih spesifik sampai kepada tingkat kecamatan dan memudahkan untuk pengambil kebijakan atau pihak-pihak terkait dalam memutuskan prioritas penanganan masalah kemiskinan dan kesenjangan ekonomi.

2. Pemerintah selaku pengambil kebijakan mampu memanfaatkan hasil pengelompokan sebagai salah satu cara menangani masalah kemiskinan dan kesenjangan yang beragam di Jawa Tengah dengan langkah yang tepat dan sesuai dengan karakteristik daerahnya.

\section{Referensi}

[1] Ambarwati. 2014. Pengelompokkan Berita Indonesia Berdasarkan Histogram Kata Menggunakan Self-Organizing Map. Jurusan Teknik Komputer, Intituto Profissional de Canossa, Dili. Vol.8,No.1.

[2] Amelia, Mia. (2012). Penerapan Regresi Spasial Untuk Data Kemiskinan Kabupaten di Pulau Jawa (Skripsi). Bogor : Departemen Statistika, Fakultas Matematika dan Ilmu Pengatahuan Alam, Intitut Pertanian Bogor.

[3] Badan Pusat Statistik Indonesia. Data dan Informasi Tahun 2015. http://www.bps.go.id. Diakses tanggal 01 Juni 2017 pukul 08.00.

[4] Badan Pusat Statistik. 2015. Berbagai Data Kondisi Indonesia Tahun 2015. Diakses tanggal diakses http://bps.go.id pada tanggal 30 Mei 2017, pukul 13.25.

[5] Bappeda. 2015. Data Pengelompokan Wilayah Jawa Tengah. Dikases di http://www.bappenas.go.id/ pada tanggal 13 Mei 2017, pukul 11.45.

[6] Cholili, Fatkhul Mufid. (2014). Analisis Pengaruh Pengangguran, Produk Domestik Regional Bruto (PDRB), dan Indeks Pembangunan Manusia(IPM) Terhadap Jumlah Penduduk Miskin. Malang : Jurusan Ilmu Ekonomi, Fakultas Ekonomi dan Bisnis, Universitas Brawijaya. Jurnal Ilmiah.

[7] Damarjati, Annisa Ganis. 2010. Analisis FaktorFaktor yang mempengaruhi Kesenjangan Pendapatan di Propinsi Jawa Tengah. Skripsi Program Sarjana Fakultas Ekonomi Universitas Diponegoro.

[8] Fauzy, Akmad. 2009. Statistik Industri. Jakarta : Penerbit Erlangga

[9] Guthikonda, S.M. 2005. Kohonen SelfOrganizing Maps. Diakses di http://www.shy.am/wpcontent/uploads/2009/01/kohonen-selforganizing-maps-shyam-guthikonda.pdf Diakses pada tanggal 13 Mei 2017, pukul 10.15.

[10] Septianusa, dkk. 2014. Karakteristik dan Segmentasi Pertanian Padi menggunakan Algoritma Self Organizing Maps (SOMs) Kohonen. Prosiding Seminar Nasional Menuju 
Masyarakat Madani dan Lestari. Universitas Islam Indonesia ISBN 978-979-98438-9-0.

[11]Thenmozhi, dkk . 2014. Clustering Breast Cancer Dataset using Self-Organizing Map Method. International Journal of Advanced Studies in Computer Science and Engineering, vol 3, issue 12014. 